\title{
Characterization of granite and limestone powders for use as fillers in bituminous mastics dosage
}

\author{
BRENO BARRA $^{1}$ LETO MOMM $^{1}$, YADER GUERRERO ${ }^{1}$ and LIEDI BERNUCCI ${ }^{2}$ \\ ${ }^{1}$ Programa de Pós-Graduação em Engenharia Civil/PPGEC, Universidade Federal de Santa Catarina/UFSC, \\ Rua João Pio Duarte Silva, s/n, 88040-970 Florianópolis, SC, Brasil \\ ${ }^{2}$ Escola Politécnica da Universidade de São Paulo/EPUSP, Departmento de Engenharia de Transportes, \\ Rua Prof. Almeida Prado, Trav. II, 83, 05508-970 São Paulo, SP, Brasil
}

Manuscript received on April 25, 2013; accepted for publication on December 10, 2013

\begin{abstract}
This paper discusses the importance of studies on materials known as fillers from different mineral origins, used in asphalt mixes, specifically in the formulation of mastics. The research was carried out on samples of limestone and granite rock filler and asphalt binder (50/70). The samples were evaluated through semiquantitative chemical analyses by $\mathrm{X}$-ray fluorescence, granulometry by low angle laser emission, scanning electron microscopy, softening point tests, penetration tests, and aggregate-asphalt binder and aggregatemastic adhesion tests. The results highlighted convergent trends, indicating that the active behavior of the fillers in the mastic formulation is not related to the size of the particles, but rather to their form, surface texture, specific surface area and mineralogical nature, allowing the filler activity concept to be divided into two components: physical (hardening) and chemical (adhesion).
\end{abstract}

Key words: characterization, fillers, granite, limestone, bituminous mastics.

\section{INTRODUCTION}

In general, fillers are added to asphalt mixes to fill in the voids formed by the larger aggregate particles, in order to stabilize these particles and to increase the post-compaction resistance of the mixes. The most diffuse technical analysis on the factors responsible for these effects indicated that the most important parameter is the granulometry (Al-Suhaibani et al. 1992).

The role of filling in the voids formed by the larger particles in the arrangement of the aggregate gradations is attributed to the small-sized particles, specifically under $75 \mu \mathrm{m}$ and above $40 \mu \mathrm{m}$, and

Correspondence to: Breno Barra

E-mail: brenobarra@gmail.com / breno.barra@ufsc.br these small particles are also related to the increase in the rigidity and the post-compaction resistance of the mixes (Aashto 2000).

On the other hand, some researchers have found that the smaller particles of the filler, under $37 \mu \mathrm{m}$

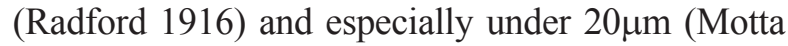
and Leite 2000), or even all of them together (Ruiz 1943), remain in suspension and form mastics when they are mixed with the asphalt binders, adsorbing part of their components, provoking an increase in the binder viscosity and consequently improving the rigidity of the mixes (Rao and Sen 1973). Puzinauskas (1969) supports that both functions are developed simultaneously by the fillers, subdividing their behavior in two parts: inert and active. 
Although there have been extensive scientific approaches to determining their characteristics, the behavior of fillers is still a controversial subject among researchers worldwide, particularly with regards to the factors that influence the physical and chemical actions of the active component of these materials, when they are added to the asphalt mixes, specifically in the formulation of mastics (Sebaaly et al. 2003, Santana 1995, Anderson et al. 1992).

In this context, the objective of this research is to discuss the importance of studies on materials known as fillers from different mineral origins, such as limestone and granite powders, specifically in the formulation of mastics used in asphalt mixes, evaluating their chemical and physical characteristics in interactive processes.

The results of this study emphasize the importance of investigating the way in which the addition of fillers modifies the physical and chemical characteristics of asphalt binders in mastic formulations, highlighting positive and negative aspects.

\section{MATERIALS AND METHODS}

Limestone and granite powders were the materials chosen to be studied in this research, because of their ample use in many Engineering activities, especially in the pavement sector where they undertake the roll of filler in the formulation of asphalt mastics destined to improve the mechanical behaviour of asphalt mixes to be applied in the field.

Furthermore, the asphalt binder 50/70 was used to formulate the granular-asphalt binder and granular-mastic systems.

The analysis of filler types and mastics was carried out through the following test methods: semiquantitative chemical analysis by X-ray fluorescence, granulometry by low angle laser emission, scanning electron microscopy (SEM), softening point, penetration, aggregate-asphalt binder adhesion and aggregate-mastic adhesion tests.

\section{RESULTS AND DISCUSSION}

The experimental analysis carried out to characterize the granite and the limestone powders are described in the following sections.

SEMI-QUANTITATIVE CHEMICAL ANALYSIS By X-RAY

FLUORESCENCE

The mineralogical compositions of the two fillers (limestone and granite powders) were determined by semi-quantitative chemical analysis using $\mathrm{X}$-ray fluorescence and the results obtained are described below.

The granite powder samples were composed of quartz $(35.0 \%)$, albite $(33.0 \%)$, zinnwaldite $(12.0 \%)$, microclinium $(18.0 \%)$ and caulinite $(2.0 \%)$. It is important to emphasize that the feldspate group comprises the minerals albite and microclinium, while the mica group includes the mineral zinnwaldite. All of the minerals defined in the semi-quantitative analysis are rich in silica contents and, hence, they are electronegative and classified as felsic or acidic minerals.

The limestone powder samples were composed of calcite $(90.0 \%)$, dolomite $(6.0 \%)$ and quartz $(4.0 \%)$. Calcite has one of the most common mineral compositions, comprising calcium carbonate $\left(\mathrm{CaCO}_{3}\right)$, usually white or uncolored, but sometimes gray, red, green, blue or yellow. Dolomite is a double calciummagnesium carbonate $\left(\mathrm{CaMg}\left(\mathrm{CO}_{3}\right)_{2}\right)$ composed of rhombohedric crystals which can be rose, white, gray, green, brown, black, or uncolored (Dpm/Unesp 2012). From this description it can be inferred that calcite is associated with positive electrical charges (electropositive) and thus limestone powder was also used as a filler in this research.

GRANULOMETRIC ANALYSIS BY LOW ANGLE LASER EMISSION

In order to verify the percent distribution of the filler particles (limestone and granite powders) with higher precision, granulometric analysis by way of low angle laser emission tests were carried out and the results are given in Figures 1 and 2. 


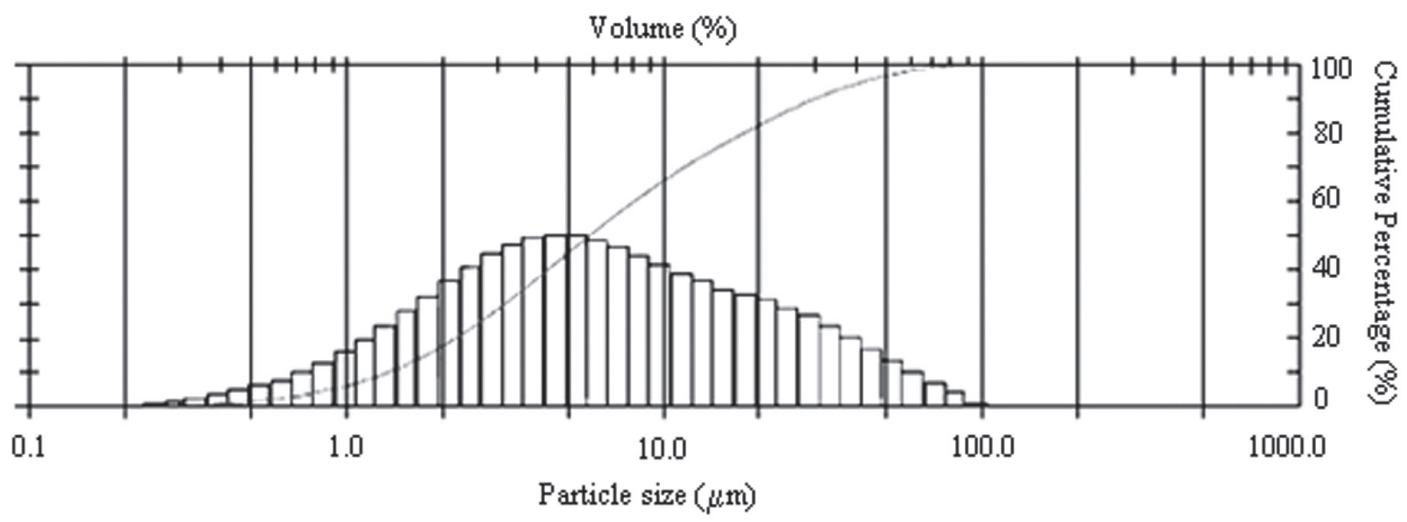

Fig. 1 - Percent distribution of the limestone powder particles.

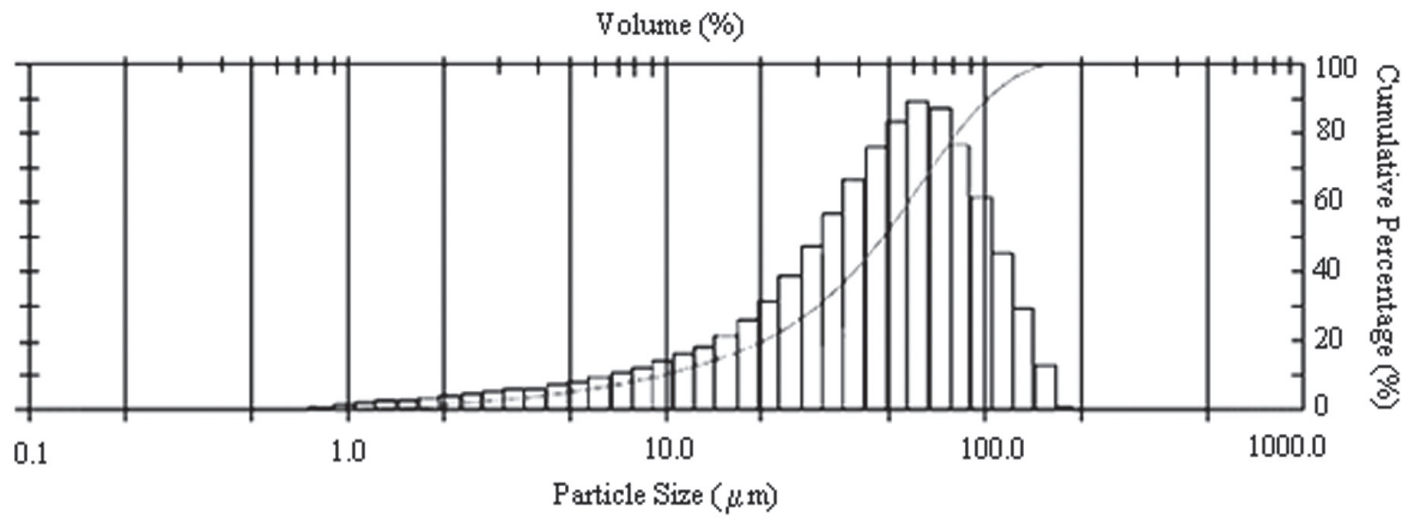

Fig. 2 - Percent distribution of the granite powder particles.

The histograms shown in Figures 1 and 2 indicate that the percentage of particles under $37 \mu \mathrm{m}$ and $20 \mu \mathrm{m}$ (indicated by the curved line) reached the following cumulative values: $94.82 \%$ and $84.81 \%$ for the limestone powder and $43.77 \%$ and $22.87 \%$ for the granite powder, respectively. The tests also provided values for the specific surface areas of these materials, which were, $0.7225 \mathrm{~m}^{2} / \mathrm{g}$ (limestone powder) and $0.1311 \mathrm{~m}^{2} / \mathrm{g}$ (granite powder).

\section{SCANNING ELECTRON MiCROSCOPY}

The form and texture of the filler particles were verified by the analysis of images captured through scanning electron microscopy (SEM) (Figures 3 and 4).

In Figures 3 and 4 it is possible to note the nonspherical form of the particles and they are rounded with sharp indentations with a rough superficial texture and specific points of high porosity. These characteristics acting together contribute to a good adhesion between the filler and the asphalt binder.

\section{SOFTENING POINT TEST}

The softening point tests (Abnt Nbr 6560 2008) were carried out on the mastics formulated with the addition of limestone and granite powders, both with $6.0 \%$ (by weight) of asphalt binder content, in order to make more precise comparisons of the effects related to the incorporation of each material. The quantity of $6.0 \%$ was chosen based on the aggregate gradation of the asphalt mixes used in the research developed by Barra (2009), which was formulated with $6.0 \%$ of particles passing through the $0.075 \mathrm{~mm}$ sieve size. 


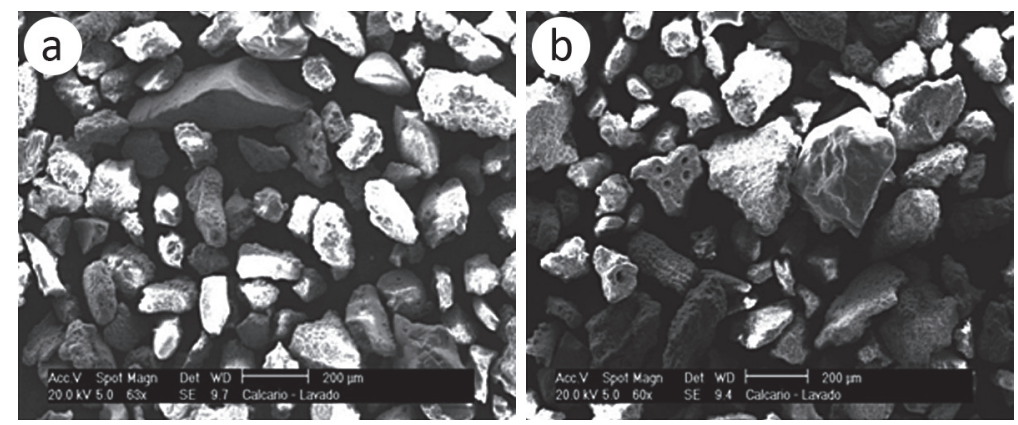

Fig. 3 - SEM micrographs of the limestone powder particles: magnifications of (a) 63 times and (b) 60 times.
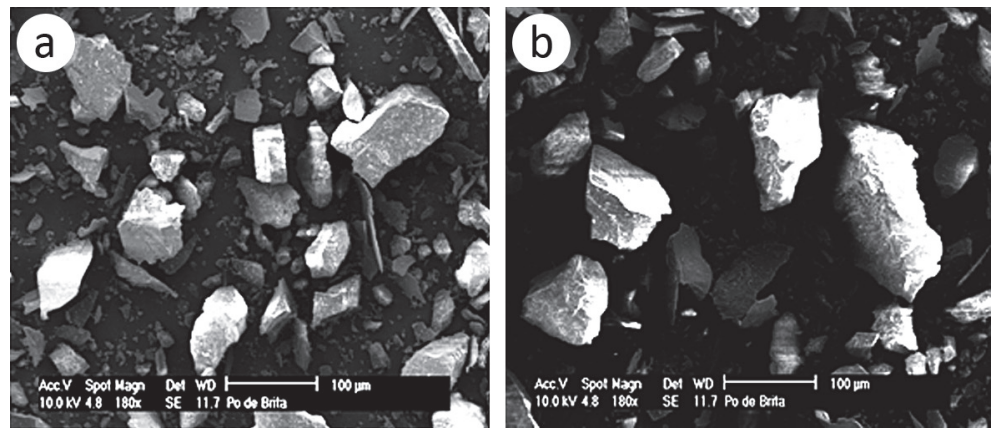

Fig. 4 - SEM micrographs of the granite powder particles: magnification of $(\mathbf{a}, \mathbf{b}) 180$ times.

The experimental procedure comprised three distinct stages: analysis of pure asphalt binder samples and samples with $6.0 \%$ of fillers added tested on the same day as the mastic formulation, and samples with $6.0 \%$ of fillers added tested five days after the mastic formulations. The aim of this latter procedure was to verify whether during this period any long-range chemical reaction could contribute decisively to the modification of the original characteristics of the asphalt binders.

To minimize the dispersion of the results during each stage of the above-mentioned experimental procedure, the samples were produced from the same mixing procedure and tested with the same flame height, without interruptions between the sample and water exchanges, maintaining a progressive increase in the water temperature of $0.5^{\circ} \mathrm{C}$ per minute. It is emphasized that the results shown in Table I are the averages of 20 tests (total of 20 pairs of samples) for each stage and for each filler type, respectively, totalizing 100 tests.
TABLE I

Results of the softening point tests.

\begin{tabular}{ccc}
\hline \multirow{2}{*}{ Stage } & Sample type & Average \\
\cline { 3 - 3 } & & $\left({ }^{\circ} \mathrm{C}\right)$ \\
\hline \multirow{2}{*}{ First } & Pure asphalt binder & 49.5 \\
\hline \multirow{2}{*}{ Second } & Mastic with limestone powder & 51.8 \\
& Mastic with granite powder & 52.1 \\
\hline \multirow{2}{*}{ Third } & Mastic with limestone powder & 54.0 \\
& Mastic with granite powder & 53.0 \\
\hline
\end{tabular}

Analyzing the results obtained with pure asphalt binder samples, it is important to emphasize that according to the softening point test standard (Abnt Nbr 6560 2008) the asphalt binder 50/70 used in the research reaches values above the minimum recommended $\left(46.0{ }^{\circ} \mathrm{C}\right)$ by the referred technical standard in relation to softening point, and the result for the pure asphalt binder sample submitted to the tests was $49.5^{\circ} \mathrm{C}$, i.e., $3.5^{\circ} \mathrm{C}$ above the minimum limit specified.

Interpreting the behavioral trends of the mastics in Table I, the addition of filler has a 
notable influence, with an increase of $2.6^{\circ} \mathrm{C}$ and $2.3{ }^{\circ} \mathrm{C}$ in the softening point values being observed for the samples tested on the same day on which the addition of granite and limestone powders, respectively, were carried out, in comparison to the pure asphalt binder samples.

For the mastics tested five days after the addition of the fillers, a slight increase in the values was verified, but with greater repeatability for all of the tests, in comparison to the results obtained in the first stage. This suggests that a rest period should be applied after the formulation of the mastics to provide a suitable arrangement of the filler particles, in order to an interface contact to occur and a chemical bond with the asphalt binder to be formed, guaranteeing more stability in terms of the mastic behavior.

These results enable the following verifications: since the ionic characteristic of the granite powder differs from that of the limestone powder and, as mentioned above, the electronegative materials (granite powder) have lower chemical activity than the electropositive materials (limestone powder), it would be expected that if this chemical characteristic prevails in the hardening process, the mastics with limestone powder added would present higher values than those with granite powder. However, this was not the case, even five days after the addition process.

Another factor which did not contribute to the mastic hardening process, in contrast to findings by applying some of the approaches described above, was the quantity of filler particles under $37 \mu \mathrm{m}$ or $20 \mu \mathrm{m}$, since despite these two materials having very different percentages of particles under these dimensions, as illustrated in Figures 1 and 2, they had very similar behaviors.

The specific surface area was not an important parameter in terms of differentiating the active behaviors of the filler types tested. In relation to the modification of the original physical characteristics of the asphalt binder, specifically the viscosity, there were no notable differences in the results related to the filler that presented the largest specific surface area, i.e., the limestone powder, compared with the other filler, as expected.

\section{Penetration Test}

The penetration tests (Abnt Nbr 6576 1998) were performed using the formulation procedures described above for the softening point tests. However, they were carried out applying only two of the stages detailed in Table I, that is, with pure asphalt binder samples and with mastics containing $6.0 \%$ (by weight) of equal amounts of granite and limestone powders.

The tests with the mastic samples were carried out on the same day as the addition of fillers, as shown in Table II, and the average values were calculated after performing 10 tests for each stage and for each filler type, respectively, totalling 30 tests.

TABLE II

Results for the penetration tests.

\begin{tabular}{ccc}
\hline Stage & Sample type & Average \\
\cline { 3 - 3 } & & $(0.1 \mathrm{~mm})$ \\
\hline First & Pure asphalt binder & 50.2 \\
\hline \multirow{2}{*}{ Second } & Mastic with limestone powder & 33.8 \\
& Mastic with granite powder & 34.2 \\
\hline
\end{tabular}

The results for the softening point tests in Table I show only a slight hardening five days after the addition of filler. Thus, since the asphalt binder and the filler samples used in the penetration tests were the same as those used in the softening point tests, it can be inferred that the same behavioral trend would be observed in the penetration tests, and consequently this procedure was not repeated.

On analyzing the results obtained with pure asphalt binder samples in Table II, it can be verified that the samples were also within the specified limits of the test standard (Abnt Nbr 6576 1998), which recommends minimum value of $50.0(0.1 \mathrm{~mm})$ for the asphalt binders 50/70. 
Both mastic samples with $6.0 \%$ of fillers maintained the same behavioral trend, despite the expected reduction of the penetration values, presenting very close results, thus confirming the above remarks regarding the softening point test results.

\section{ADHESION TEST}

In order to verify that the fillers promoted adhesion in the aggregate (formed by crushed granite rock particles)-asphalt binder and aggregate-mastic systems, the specifications of the test standard (Dner-me 78/94 1994) were considered and the tests were conducted in two stages: evaluating the adhesion in the aggregate-pure asphalt binder system and, subsequently, in the aggregate-mastic (with $6.0 \%$ of limestone and granite powders, respectively) system. The results are given in Figure 5.
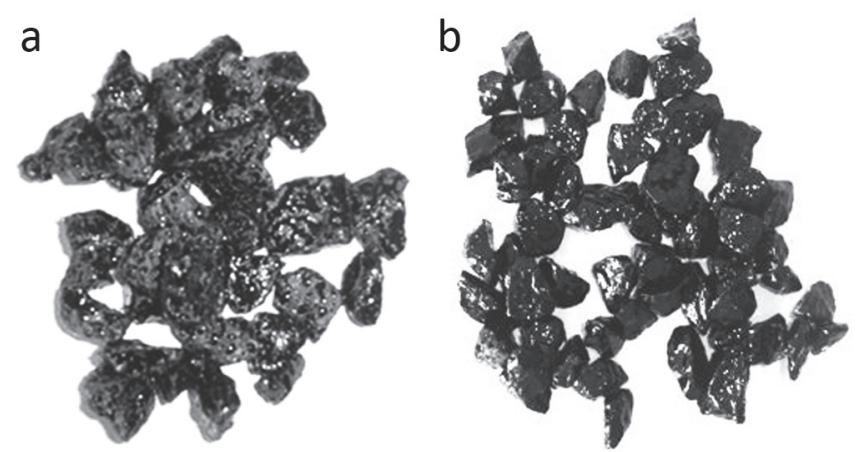

Fig. 5 - Samples analyzed in the adhesion tests with (a) aggregatepure asphalt binder system and (b) aggregate-mastic system with $6.0 \%$ of limestone powder.

In Figure 5 it is clear that the mineralogical nature of the fillers is an important factor in the adhesion of the aggregate-asphalt binder and aggregate-mastic systems. This Figure illustrates the occurrence of two events, which are, the detachment of the film from the pure asphalt binder and the mastic with $6.0 \%$ of granite powder from the surface of the crushed granite rock particles, i.e., these two systems presented the same behavior in terms of adhesion. On the other hand, the mastic with $6.0 \%$ of limestone powder presented better efficiency in terms of adhesion to the crushed granite rock particles, although a few and very small detached points do appear in the samples.

Detached points occurred because the fillers comprised of rocks with electropositive characteristics (such as calcite) adsorbed the molecules of the asphalt binder by chemisorption and during this process the filler particles start to react chemically with the naphthenic acids of the asphalt binders, forming calcium naphthenate, which is insoluble in water (Santana 1995) and protects the asphalt binder film that covers the aggregate particles.

The same acid characteristics are inherent and intrinsic to the asphalt binder and to the crushed granite rock particles. Therefore, the granite powder does not achieve the same success as the limestone powder, the latter having favorable chemical characteristics as mentioned above.

The cohesive and interfacial adhesion in the asphalt binder-filler (during the formulation of the mastics) and aggregate-mastic systems, respectively, are directly related to the chemical adsorption (chemisorption) of the asphalt binder by the filler and to the Lewis acid-base interactions, because when there is contact between these materials several chemical bonds are formed, similarly to the case of the ionic bonds, which are very strong and include the formation of new compounds (e.g., the calcium naphthenate). 
Thus, considering these chemical aspects, it is possible to infer that the mineralogical nature of the material is the main factor determining the degree of adhesion of the fillers to the asphalt binders and is the reason for the limestone powder providing more efficient adhesion than the granite powder.

Regarding the specific surface area, although this variable presented no correlation regarding the modification of the physical characteristics of the asphalt binders, considering the chemical characteristics of the fillers, there was a notable improvement in the adhesion in the aggregatemastic system, directly related to the occupation of the area by unit mass, in which the limestone powder $\left(0.7225 \mathrm{~m}^{2} / \mathrm{g}\right)$ presented better results than the granite powder $\left(0.1311 \mathrm{~m}^{2} / \mathrm{g}\right)$.

This finding is due to the increase in the specific surface area which contributes to potentializing the chemical adsorption of the asphalt binder by the filler by increasing the interfacial contact area between the two surfaces of the materials, amplifying the electrical field of molecular interaction most favorable to the aggregate-asphalt binder system adhesion, since these aspects have compatibility with the ionic characteristic considered suitable for filler particles, i.e., electropositivity.

\section{CONCLUSIONS}

Based on the results of the tests carried out in this research, it can be concluded that the active behavior of the fillers is due to the simultaneous integration of two components: physical and chemical.

The physical component was found to be influenced mainly by the form and texture of the particles, which guarantee a firm adhesion of the asphalt binder film to the surface of the particles, forming mastics which are harder than the pure asphalt binder samples. These conditions lead to the modification of the asphalt binder viscosity as verified by the results for the softening point and penetration tests. The porosity, despite being a physical characteristic which also contributes to a better adhesion of the fillers to the asphalt binders, could not be studied in detail from the tests carried out.

In relation to the chemical component, the increase in the electrical field provided by the larger specific surface area together with the mineralogical nature of the fillers were decisive characteristics in terms of the increase in the electrical field of molecular attraction and the formation of the ionic bonds related to the Lewis acid-base interactions, respectively.

On analyzing the physical aspects, the two filler samples (limestone and granite powders) had almost identical behaviors, and the results for the modification of the original characteristics of the asphalt binder did not show significant differences. Chemically, however, the differences were very notable, the best adhesive behavior being verified for the mastics formed with the addition of the filler which provided the largest electrical field of molecular interaction and with positive electrical charge (cationic), i.e., the limestone powder.

Hence, the results of this research indicate that the adhesion action of the filler is not related to the size of the particles but instead to their form and mineralogical nature. In addition, the texture and specific surface area are variables which need to be considered in this context.

\section{ACKNOWLEDGMENTS}

We would like to thank the Universidade Federal de Santa Catarina (UFSC) and the Escola Politécnica da Universidade de São Paulo (EPUSP) for allowing us to use their material and premises, as well as the Conselho Nacional de Desenvolvimento Científico e Tecnológico (CNPq) for the financial support of this research.

\section{RESUMO}

O objetivo desta pesquisa é discutir a importância de estudos sobre materiais denominados fíleres de diferentes origens, para utilização na composição de 
misturas asfálticas, mais especificamente na formulação de mástiques. Os testes laboratoriais foram executados com amostras finamente pulverizadas de rocha calcária e granítica, além do ligante betuminoso classificado como 50/70. As amostras foram avaliadas a partir dos seguintes testes: análise química semi-quantitativa por fluorescência de raio-X, granulometria por emissão de raio laser de baixo ângulo, microscopia eletrônica de varredura, ponto de amolecimento, penetração, adesividade dos sistemas agregado-ligante betuminoso puro e agregado-mástique. Os resultados obtidos enfatizam tendências convergentes, indicando que a comportamento ativo dos fíleres na formulação dos mástiques não está relacionado com o tamanho das partículas, mas sobretudo com a sua forma, textura superficial, área da superfície específica e natureza mineralógica, permitindo que o conceito de atividade dos fíleres possa ser dividido em duas componentes: física (enrijecimento) e química (adesão).

Palavras-chave: caracterização, fíleres, granito, calcário, mástique betuminoso.

\section{REFERENCES}

AASHTO. 2000. Hot-mix asphalt paving handbook. American Association of State Highway Transportation Officials. Washington, DC: United States National Research Council (U.S.), 219 p.

ABNT NBR 6560.2008. Especificações dos cimentos asfálticos de petróleo (CAP) - ensaio de ponto de amolecimento anel e bola. Associação Brasileira de Normas Técnicas.

ABNT NBR 6576. 1998. Especificações dos cimentos asfálticos de petróleo (CAP) - ensaio de penetração. Associação Brasileira de Normas Técnicas.

Al-Suhaibani A, Al-MudaiheEm J AND Al-FozAn F. 1992. Effect of filler type and content on properties of asphalt concrete mixes. American Society for Testing and Materials (ASTM). ASTM STP 1147, Philadelphia: Richard C Meininger, Philadelphia, USA, p. 107-129.
ANDERSON DA, DONGRE R AND CHRISTENSEN DW. 1992. Effect of minus $\mathrm{N}^{\circ} 200$-sized aggregate on fracture behavior of dense-graded hot-mix asphalt. Philadelphia: American Society for Testing and Materials (ASTM). ASTM STP 1147, Philadelphia: Richard C Meininger, Philadelphia, USA, p. 154-176.

BARRA BS. 2009. Avaliação da Ação da Água no Módulo Complexo e na Fadiga de Misturas Asfálticas Densas. Tese de Doutorado. Universidade Federal de Santa Catarina (UFSC). Florianópolis, Brasil. (Unpublished).

DPM/UNESP. 2012. Departamento de Petrologia e Metalogenia da Universidade Estadual de São Paulo. Museu de Minerais e Rochas Heinz Ebert, Portal Campus Rio Claro. http://www.rc.unesp.br/museudpm. Last access in March 2013.

DNER-ME 78/94. 1994. Agregado Graúdo: Adesividade ao ligante betuminoso. Rio de Janeiro: Departamento Nacional de Estradas de Rodagem.

MotTA LMG AND LeITE LFM. 2000. Efeito do fíler nas características mecânicas das misturas asfálticas. Gramado, RS: $11^{\circ}$ Congresso Pan-Americano de Engenharia de Trânsito e Transporte, p. 1019-1030.

PUZINAUSKAS VP. 1969. Filler in asphalt mixtures. Maryland, USA: The Asphalt Institute - Research Report 69-2.

RADFORD TA. 1916. The construction of road and pavements. New York: Edited by McGraw-Hill Company, Inc. $5^{\text {th }}$ ed., $432 \mathrm{p}$.

RAO SK AND SEN BR. 1973. Evaluation of mineral fillers for asphalt paving mixtures. Highway Research Record 468: 100-108.

RUIZ C. 1943. Sobre las propriedades mecanicas del sistema filler-betún. Argentina: LEMIT, Série II 8: 220-240.

SANTANA H. 1995. Considerações sobre os Nebulosos Conceitos e Definições de Filler em Misturas Asfálticas. Cuiabá, MT: Anais da 29a Reunião Anual de Pavimentação (RAPv), Vol. 1, Associação Brasileira de Pavimentação (ABPV).

SebaAly PE, Hitti E AND Weitzel D. 2003. Effectiveness of lime in hot-mix asphalt pavements. Transportation Research Record 1832, Paper $\mathrm{N}^{\circ} 03-2126$, p. 34-40. 